\title{
The Effectiveness of Government Debt and Transfers as Insurance*
}

\author{
Martin Flodén ** \\ SSE/EFI Working Paper Series in Economics and Finance
}

No. 377

March 15, 2000

\begin{abstract}
Government debt and redistributive taxation can help people to smooth consumption when facing uninsurable individual specific risk. I examine the effects that variations in public debt and transfers have on risk sharing, efficiency, and the distribution of resources. I find that risk sharing can be improved significantly by both debt and transfers, but that debt has adverse effects on equity. When used in isolation, debt will enhance welfare if transfers are lower than optimal. However, the beneficial effects of public debt vanish if transfers are used optimally.
\end{abstract}

JEL classification: E2, E6, H2, H6

Keywords: redistributive taxation; public debt; idiosyncratic risk; fiscal policy; social insurance; welfare measures

\footnotetext{
${ }^{*}$ I thank David Domeij, Torsten Persson, Stephen Williamson, an anonymous referee, and various seminar participants for comments on a previous version of the paper. Financial support from The Jan Wallander and Tom Hedelius Foundation and Carl Mannerfelt's Fund is gratefully acknowledged.

** Stockholm School of Economics, Box 6501, SE-113 83 Stockholm, Sweden. E-mail: Martin.Floden@hhs.se. Homepage: www.hhs.se/personal/floden
} 


\section{Introduction}

If individuals are borrowing constrained and private insurance markets are missing, government debt and redistributive taxation can help individuals to smooth consumption when facing idiosyncratic income risk, as has been demonstrated in work by Woodford (1990) (for debt), and Varian (1980) (for taxation). ${ }^{1}$ On the one hand, it can be argued that insurance against individual specific risk is most directly provided by the tax and transfer system. On the other hand, debt may enhance risk sharing without distorting labor supply and savings to the same extent as transfers do. These issues are the main concern in my paper, and I will claim that both arguments have some merit.

I consider a model economy with incomplete markets and a large number of agents, who differ in ability and are hit by different wage shocks. Since private insurance markets do not exist, agents self-insure by building up buffer stocks of private savings when wages are high. A public transfer system can reduce individual income risk in this environment by shifting resources from households with temporarily high income to households with lower income. Public debt can improve risk sharing by increasing liquidity in the economy. One way of understanding this effect is to think of an increase in public debt as a relaxed borrowing constraint. Another way is as follows: When debt increases, physical capital is crowded out and the equilibrium interest rate increases. The cost of postponing consumption to build up buffer stocks is then reduced, and agents will choose to hold more assets in equilibrium.

In addition to affecting risk sharing, debt and transfers change the distribution of resources. An increase in transfers reduces inequality since the transfer system redistributes from highincome to low-income households. An increase in debt, on the other hand, mostly benefits wealthy households. They gain from the higher return on capital while all agents suffer from the reduction in output caused by higher taxes and crowding-out of physical capital (see Ball and Mankiw, 1995, for a discussion).

For a given policy change (i.e. a change in debt or transfers), I isolate the welfare effects stemming from changed levels of consumption, risk sharing, and inequality, respectively. The utilitarian welfare function does not distinguish these three effects from each other. Utilitarian welfare is increasing in the level of consumption, and decreasing in uncertainty and inequality.

\footnotetext{
${ }^{1}$ See for example Zeldes (1989), Jappelli (1990), and Attanasio and Davis (1996) for evidence on borrowing constraints and imperfect insurance.
} 
I obtain the separate welfare effects by using welfare measures inspired by Bénabou (1998) in addition to the utilitarian measure. The idea is to calculate certainty-equivalent consumption values for each agent. A reduction in uncertainty increases certainty-equivalent consumption for all agents, while a pure redistribution of resources reduces the certainty-equivalent consumption for some agents and increase the consumption for other agents by (at least approximately) the same amount. The difference between the sum of all agents' actual and certainty-equivalent consumption is therefore used to measure the cost of uncertainty in the economy while the distribution of certainty-equivalent consumption across agents is used to measure inequality.

The main findings in the paper are that (i) both debt and transfers can improve risk sharing substantially, (ii) transfers reduce inequality while debt has adverse effects on equity (iii) if policy is evaluated with a utilitarian welfare function, debt should be low and transfers should be high, (iv) if the welfare measure does not incorporate the distribution of resources, debt should be high and transfers should be around today's level, and (v) transfers and in particular debt can reduce the overaccumulation of capital caused by market incompleteness.

Aiyagari and McGrattan (1998) found that a positive public debt can be optimal, but that the welfare effects of debt are negligible in a model calibrated to match the US economy. I show here, within a similar framework, that the optimality of positive debt depends on transfers being lower than optimal. I also demonstrate that behind the small utilitarian welfare effects, there are fairly substantial welfare gains from improved risk sharing and welfare losses from increased inequality. The gains and losses almost cancel with Aiyagari and McGrattan's set-up, hence the small effects in the utilitarian welfare function. In general, however, variations in the debt level can have sizeable welfare effects.

Bénabou (1998) suggests evaluating policy with a measure of what he calls pure economic efficiency. This welfare measure ignores distributional effects but incorporates effects on risk sharing and levels of consumption and leisure. If policy is evaluated by this criterion, the optimal level of transfers is lower than in the utilitarian case, and debt should be as high as possible. It may therefore be justified to claim that, compared to transfers, debt provides more risk sharing relative to the distortions it imposes on the economy.

While lump-sum transfers increase average utility, transfers that are targeted at households with low income and no wealth can be harmful. As Hubbard, Skinner and Zeldes (1995) have shown, means-tested transfers weaken incentives for low-income households to save, thereby 
creating a poverty trap. Strictly means-tested transfers therefore have a strongly negative impact on equity and also on welfare. However, if transfers are reduced less than one-to-one with additional income and wealth, and if the transfer system is small or modest, means testing may be effective. It appears particularly important not to reduce transfers in response to wealth accumulation.

I have previously claimed that transfers and debt are distorting. This statement needs a qualification. Since markets are incomplete, the economy may be inefficient in the sense that there is overaccumulation of capital and labor supply is inefficiently allocated between agents. ${ }^{2}$ Enhanced risk sharing can therefore improve the allocation of consumption and leisure over time. I find that in the absence of a social insurance system, introducing lump-sum transfers would increase the utility of a representative agent whose consumption and working hours are the economy averages. Transfers can consequently enhance welfare even if effects on risk sharing and equality are ignored. The same holds for debt - even if transfers and debt are at the benchmark levels (8.2 percent and 67 percent of GDP, respectively), an increase in debt will raise the representative-agent utility (albeit only marginally).

The focus here is on insurance against individual specific risks, and I make the simplifying assumption that aggregates are constant. Hence, I examine the choice of long-run or average policy, but I do not consider how debt and transfers should vary over the business cycle or in response to aggregate shocks (see Barro, 1979, Lucas and Stokey, 1983, and Chari, Christiano, and Kehoe, 1994, for these issues). Furthermore, Gale (1990) shows that government debt can improve risk sharing between generations. No such issues arise here, since agents are infinitely lived and there is no aggregate uncertainty.

The plan of the paper is as follows. The model is presented in the next section. In Section 3, I define the welfare measures and describe how utilitarian welfare effects are decomposed into distortion (or level) effects, insurance effects, and redistribution effects. The results are presented in Section 4. Section 5 concludes.

\footnotetext{
${ }^{2}$ Aiyagari (1995) demonstrates that because of this overaccumulation of capital, the optimal tax rate on capital income is positive.
} 


\section{The model}

\subsection{Production and factor prices}

There is a continuum of firms which have Cobb-Douglas production functions and behave competitively in product and factor markets. Let $K$ denote the aggregate capital stock, $H$ the aggregate labor supply in efficiency units, and $X$ the productivity of labor. There is no aggregate uncertainty in the economy. Aggregate production is then given by

$$
Y=F(X, K, H)=K^{\theta}(X H)^{1-\theta} .
$$

Factor market clearance requires that the interest rate is

$$
r=F_{K}(X, K, H)-\delta
$$

where $\delta$ denotes the depreciation rate of capital, and that the wage rate is

$$
w=F_{H}(X, K, H) .
$$

Labor productivity grows at the exogenous rate $g$ and initial productivity is normalized to unity, hence productivity at time $t$ is $X_{t}=(1+g)^{t}$. Only balanced growth paths where aggregate output, capital and consumption grow at rate $g$ while aggregate labor supply is constant will be considered. The interest rate will therefore be constant in equilibrium. It will often be convenient to look at detrended variables. Define therefore

$$
\tilde{w} \equiv w / Y,
$$

which also is constant in equilibrium.

\subsection{The government}

The government issues public debt and tax labor and capital income. Tax revenues are spent on public consumption, transfers to households, and interest payments on the debt. The government budget constraint is

$$
G+B+r D=D^{\prime}-D+T
$$

where $G$ is government consumption, $B$ are transfers to agents, $D$ is the government debt, and $T$ is tax revenue. Primes denote next-period values. Government consumption is exogenous and a constant fraction of GDP, $\bar{G}=G / Y$. 
Tax revenues are levied by taxing capital and labor at the flat rates $\tau^{k}$ and $\tau^{h}$, respectively. After-tax factor prices are defined as $\bar{r}=\left(1-\tau^{k}\right) r$, and $\bar{w}=\left(1-\tau^{h}\right) \tilde{w}$.

The government chooses debt and transfers to maximize some social welfare function in the stationary balanced growth equilibrium. Thus, welfare effects accrued during the transition from the current economy to the new equilibrium are ignored.

\subsection{Households}

The model is populated by a continuum of infinitely lived agents of unit mass. Agents receive income by renting capital to firms and by supplying labor. They are born with permanently different abilities, and are in each period subject to idiosyncratic productivity shocks. Agents are borrowing constrained (that is, net financial wealth cannot be negative) and do not have access to private insurance markets. ${ }^{3}$ To smooth consumption over time, and to self insure against future income risk, agents therefore accumulate buffer stocks of the safe asset in good times.

Let $s_{t}$ denote an agent's productivity state at time $t$. The productivity process is a finite state Markov chain, $s \in \mathbf{S}$ with transition probabilities $\Gamma\left(s, s^{\prime}\right)$ denoting the probability of transition from productivity state $s$ today to $s^{\prime}$ tomorrow. Moreover, let $q(s) \equiv q$ be the productivity associated with state $s$.

Each agent is endowed with one unit of time, which is divided between labor, $h$, and leisure, l. Income can be consumed or saved in a safe asset. Let $b$ denote a transfer from the government, $a$ the agent's asset holdings at the end of the previous period, and $c$ consumption. Define then $\widetilde{b}=b / Y, \tilde{a}=a / Y$, and $\tilde{c}=c / Y$. Thus an agent's budget constraint is

$$
(1+g) \tilde{a}^{\prime}=\widetilde{b}+\bar{w} q h+(1+\bar{r}) \tilde{a}-\tilde{c}
$$

Agents are also subject to a no-borrowing constraint,

$$
\tilde{a} \geq 0
$$

Asset holdings, $\tilde{a}$, are restricted to belong to $\mathbf{A}=[0, \bar{a}]$ where $\bar{a}$ is chosen high enough never to be a binding condition.

\footnotetext{
${ }^{3}$ These market imperfections are imposed exogenously. A growing literature (see Atkeson and Lucas, 1995, and Krueger and Perri, 1998, for recent contributions) studies the feasibility of private insurance markets under asymmetric information. The paper by Cole and Kocherlakota (1998) supports the view that a limited number of financial assets (e.g. one risk-free bond) may provide the best feasible insurance.
} 
The instantaneous utility function is

$$
u(c, h)=\frac{c^{1-\mu} \exp \left[-(1-\mu) \zeta h^{1+\gamma}\right]}{1-\mu},
$$

where $\zeta$ is a constant, $\mu$ is the risk aversion for consumption fluctuations, and $1 / \gamma$ is the laborsupply elasticity. This utility function is consistent with aggregate hours worked being constant in a growing economy (see King, Plosser, and Rebelo, 1988). We can rewrite the utility as

$$
u(X, c, h)=\left(X Y_{0}\right)^{1-\mu} u(\tilde{c}, h)
$$

Agents maximize their expected life-time utility,

$$
U_{0}=\mathrm{E}_{0} \sum_{t=0}^{\infty} \beta^{t} u\left(c_{t}, h_{t}\right)
$$

where $\beta$ is the time discount factor. The detrended formulation of the objective is

$$
U_{0}=Y_{0}^{1-\mu} \mathrm{E}_{0} \sum_{t=0}^{\infty} \beta^{t}(1+g)^{t(1-\mu)} u\left(\tilde{c}_{t}, h_{t}\right)
$$

The normalizations allow us to formalize a time-independent problem. The Bellman equation is

$$
v(\tilde{a}, s)=\max _{\left\{\tilde{a}^{\prime}, h\right\}} Y_{0}^{1-\mu} u(\tilde{c}, h)+\beta(1+g)^{1-\mu} \sum_{\mathbf{S}}\left[v\left(\tilde{a}^{\prime}, s^{\prime}\right) \Gamma\left(s, s^{\prime}\right)\right]
$$

subject to (1), (2), and $0 \leq h \leq 1$.

\subsection{Equilibrium}

A stationary equilibrium consists of constant tax rates $\tau^{k}$ and $\tau^{h}$, a constant government debt, $\bar{D} \equiv D / Y$, a transfer system, $\widetilde{b}=b(\bar{w} q h+\bar{r} \tilde{a}, \tilde{a})$; a constant interest rate $\bar{r}$ and wage rate $\bar{w}$; time invariant decision rules for agents' asset holdings, $\tilde{a}^{\prime}=a(\tilde{a}, s)$, and hours worked, $h=h(\tilde{a}, s)$; a measure of agents over the state space, $\lambda(\tilde{a}, s)$; aggregate values for transfers to households, $\bar{B} \equiv B / Y=\int \tilde{b} d \lambda$, for asset holdings, $\bar{A}=\int a(\tilde{a}, s) d \lambda$, and for the number of efficiency hours worked, $H=\int q h(\tilde{a}, s) d \lambda$, such that the following equilibrium conditions are fulfilled: (i) decision rules solve agents' maximization problem, given by (3); (ii) tax revenues equal government expenses,

$$
\int_{\mathbf{A} \times \mathbf{S}} \tau^{h} \tilde{w} q h(\tilde{a}, s)+\tau^{k} r a(\tilde{a}, s) d \lambda=\bar{B}+(r-g) \bar{D}+\bar{G}
$$


(iii) factor markets clear; (iv) aggregate savings are equal to firms' demand for capital plus government debt,

$$
\bar{A}=\bar{K}+\bar{D},
$$

where $\bar{K} \equiv K / Y$; and (v) the measure of agents over the state space is invariant, i.e.

$$
\lambda(\mathbf{a}, \mathbf{s})=\int_{\mathbf{A} \times \mathbf{S}} P(a, s, \mathbf{a}, \mathbf{s}) d \lambda,
$$

for all $\mathbf{a} \times \mathbf{s} \subseteq \mathbf{A} \times \mathbf{S}$. The transition function $P$ is the probability that an agent with state $(a, s)$ will have a state belonging to $\mathbf{a} \times \mathbf{s}$ next period,

$$
P(\tilde{a}, s, \mathbf{a}, \mathbf{s})=\sum_{s^{\prime} \in \mathbf{s}} \mathcal{I}[a(\tilde{a}, s) \in \mathbf{a}] \Gamma\left(s, s^{\prime}\right),
$$

where $\mathcal{I}$ is an indicator function.

\subsection{Computation of equilibrium}

To find the agents' decision rules for saving and labor supply, I discretize the state space and solve for the corresponding value function and decision rules. ${ }^{4}$ To solve for the equilibrium, I use an algorithm inspired by Huggett (1993) and Aiyagari (1994). In the benchmark specification of the model, transfers are lump sum and there is a uniform tax rate on all factor incomes, $\tau=\tau^{k}=\tau^{h}$. The algorithm then consists of the following steps: Fix the transfer and the debt, and guess an interest rate, $r$, and the average efficiency hours of labor supply, $\hat{H}$. Then solve for the wage per efficiency unit of labor as a function of $r$ and $\hat{H}$, and calculate the tax rate implied by government budget balance, by setting

$$
\tau=\frac{\bar{B}+(r-g) \bar{D}+\bar{G}}{\tilde{w} \hat{H}+r(\bar{K}+\bar{D})} .
$$

The agents' decision rules are then solved for, and from these rules, the measure of agents over the state space is computed. Once we have found the measure $\lambda$, aggregates such as savings and labor supply are straightforward to calculate. If the implied aggregate saving does not equal demand for capital, or if the implied labor supply is different from the guess, then update the guesses and start over. If both equalities hold, the equilibrium of the economy with transfer $\bar{B}$ and debt $\bar{D}$ has been found.

\footnotetext{
${ }^{4}$ The state space is approximated by a grid consisting of 3700 values for asset holdings, one high and one low value for the permanent shock, and 7 values for the temporary wage level. The Markov chain for wages is approximated with the algorithm by Tauchen (1986). I use a spread of $\pm 3 \sigma_{\varepsilon} /\left(1-\rho^{2}\right)^{1 / 2}$ for the wage grid. The step size in the grid for asset holdings is increasing in wealth.
} 
In some alternative specifications, transfers are means tested. This complicates the algorithm somewhat because the total amount of transfers paid depends not only on the aggregate quantities but also on the distribution of resources across agents. I proceed as follows: First, fix $\bar{B}$ and $\bar{D}$. Then make a guess for the free parameter in the transfer system. ${ }^{5}$ Next solve for the equilibrium prices and quantities as above and calculate the implied transfers. If transfers do not sum to $\bar{B}$, adjust the levels in the transfer system and reiterate.

\subsection{Parameterization}

With two exceptions, Aiyagari and McGrattan's (1998) parameter values are used. One model period thus corresponds to one year, and I set risk aversion to 1.5, government consumption to 21.7 percent of GDP, the capital share of income to 0.30 , the depreciation rate of capital to 0.075 , and the growth rate of GDP to 1.85 percent. The discount factor $\beta$ is set to 0.9884 to get an interest rate close to 4.5 percent as in U.S. data. With the benchmark policy, government debt is 67 percent of output while transfers are lump sum and 8.2 percent of output.

The two deviations from Aiyagari and McGrattan's parameter choices regard the utility function and the productivity process. Estimations of the wage elasticity of labor supply vary widely between studies. However, most estimates of the elasticity are less than 0.5 for men and the estimated elasticity for women is typically higher than for men (see for example MaCurdy, 1981, and Altonji, 1986). I set the elasticity to 0.5, which is considerably lower than the value used by Aiyagari and McGrattan. The fraction of available time an agent devotes to labor is determined by $\zeta$, which is set so that average labor supply is approximately 0.3 in the benchmark economy.

The productivity process is calibrated as follows. Wages consist of two components, one permanent ability level, $\psi$, and one temporary component, $z_{t}$. More specifically, an agent's labor productivity as a fraction of average productivity at time $t$ is $q_{t}=e^{\psi+z_{t}}$. Across individuals, $\psi$ is iid with mean zero and variance $\sigma_{\psi}^{2}$. Productivity evolves stochastically over time according to the process

$$
z_{t}=\rho z_{t-1}+\varepsilon_{t}
$$

where $\rho$ determines the degree of persistence of shocks, and $\varepsilon$ is iid normally distributed with mean zero and variance $\sigma_{\varepsilon}^{2}$.

\footnotetext{
${ }^{5}$ The means tested transfer sytems are described in Section 4.4 below. The free parameter will be the minimum consumption level guaranteed by the insurance program.
} 
Aiyagari and McGrattan set $\rho=0.60$ and $\sigma_{\varepsilon}=0.24$. Recent evidence, for example Card (1991), Hubbard, Skinner, and Zeldes (1994), Storesletten, Telmer, and Yaron (1997), and Flodén and Lindé (1999), suggest that wage and income processes are more persistent. The values $\rho=0.90$ and $\sigma_{\varepsilon}=0.21$ are in line with estimates in these papers, and this wage process is used as the benchmark here. Both Card's and Flodén and Lindé's estimates of the standard deviation of permanent wage differences, $\sigma_{\psi}$, suggest that it is approximately 0.34 .

The parameter values for the benchmark calibration of the model are then $\mu=1.5, \gamma=2$, $\zeta=9.1449, \beta=0.9884, g=0.0185, \theta=0.3, \delta=0.075, \bar{G}=0.217, \rho=0.90, \sigma_{\varepsilon}=0.21$, and $\sigma_{\psi}=0.34$.

\section{Measuring and separating welfare effects}

A change in policy will affect the levels of consumption and leisure, the distribution of income, wealth and spending, and the amount of uncertainty agents face. This section describes how to measure welfare effects in this context, and in particular how to isolate each of these effects. The welfare decomposition I propose here is not specific to the particular model I use but should be applicable on most dynamic models with heterogenous agents and uncertainty.

It will be useful to first introduce some notation. Let $\left\{c_{s}, l_{s}\right\}_{s=t}^{\infty}$ denote a (possibly uncertain) stream of consumption and leisure from time $t$ and on. Consider then the following definitions: ${ }^{6}$

Definition 1 Life-time utility, $V$, is

$$
V\left(\left\{c_{s}, l_{s}\right\}_{s=t}^{\infty}\right)=\sum_{s=t}^{\infty} \beta^{s-t} u\left(c_{s}, 1-l_{s}\right)
$$

Definition 2 A certainty-equivalent consumption-leisure bundle, $\{\bar{c}, \bar{l}\}$, fulfills ${ }^{7}$

$$
V\left(\{\bar{c}, \bar{l}\}_{s=t}^{\infty}\right)=\mathrm{E}_{t} V\left(\left\{c_{s}, l_{s}\right\}_{s=t}^{\infty}\right)
$$

Let $C$ and $L$ be average consumption and leisure, $C \equiv \int c d \lambda$, and $L \equiv \int(1-h) d \lambda$, and let $\bar{C}$ and $\bar{L}$ denote average certainty-equivalent consumption and leisure, $\bar{C} \equiv \int \bar{c} d \lambda$, and $\bar{L} \equiv \int \bar{l} d \lambda$.

A frequently used social welfare function is the utilitarian, which is the average utility in the economy:

\footnotetext{
${ }^{6}$ To simplify notation, I ignore the fact that some aggregates grow (at rate $g$ ) over time. The strictly correct notation would date aggregates and certainty equivalents at time $t$. As long as all aggregates refer to the same $t$, there is no practical problem.

${ }^{7}$ Note that this does not define a unique combination of $\bar{c}$ and $\bar{l}$. This problem is further discussed below.
} 
Definition 3 The utilitarian social welfare, $U$, is

$$
U=\int \mathrm{E}_{t} V\left(\left\{c_{s}, l_{s}\right\}_{s=t}^{\infty}\right) d \lambda
$$

Utilitarian welfare increases if consumption or leisure increases, if inequality is reduced (since the utility function is concave), or if uncertainty is reduced (since agents are risk averse).

We are interested in evaluating welfare differences between two economies. Call these economies $A$ and $B$, and let $A$ be the benchmark economy. ${ }^{8}$ The utilitarian welfare gain of changing from economy $A$ to economy $B$ is defined as the equivalent variation premium:

Definition 4 The utilitarian welfare gain of policy change, $\omega_{U}$, is defined by

$$
\int \mathrm{E}_{t} V\left(\left\{\left(1+\omega_{U}\right) c_{s}^{A}, l_{s}^{A}\right\}_{s=t}^{\infty}\right) d \lambda^{A}=\int \mathrm{E}_{t} V\left(\left\{c_{s}^{B}, l_{s}^{B}\right\}_{s=t}^{\infty}\right) d \lambda^{B}
$$

The premium $\omega_{U}$ can be thought of as the percent of life-time consumption agents in economy $A$ are prepared to give up to get the policy change. It can be shown that

$$
\omega_{U}=\left(\frac{U^{B}}{U^{A}}\right)^{\frac{1}{1-\mu}}-1 .
$$

As already mentioned, we also want to isolate the different welfare effects. The approach I propose here is inspired by Bénabou (1998). The idea is to isolate uncertainty effects from inequality effects by calculating certainty-equivalent consumption levels for each individual. Inequality is then measured from the distribution of certainty-equivalent consumption while uncertainty is measured by comparing the differences in actual and certainty-equivalent consumption levels. To be more specific, consider the following definitions of the costs of uncertainty and inequality in an economy:

Definition 5 The cost of uncertainty, $p_{u n c}$, is defined by

$$
V\left(\left\{\left(1-p_{\text {unc }}\right) C, L\right\}_{s=t}^{\infty}\right)=V\left(\{\bar{C}, \bar{L}\}_{s=t}^{\infty}\right)
$$

Definition 6 The cost of inequality, $p_{\text {ine }}$, is defined by

$$
V\left(\left\{\left(1-p_{\text {ine }}\right) \bar{C}, \bar{L}\right\}_{s=t}^{\infty}\right)=\int V\left(\{\bar{c}, \bar{l}\}_{s=t}^{\infty}\right) d \lambda
$$

\footnotetext{
${ }^{8}$ Superscripts $A$ and $B$ denote the economy that variables correspond to, and consumption and leisure streams are the optimal choices in the respective economies
} 
The cost of uncertainty is measured in percent of consumption and is calculated from the difference between average consumption and leisure on the one hand, and the average certainty equivalents on the other hand. The cost of inequality is measured (again in percent of consumption) from the difference between the utility of consuming certainty-equivalent averages and the average of utilities.

If uncertainty increases, certainty-equivalent consumption-leisure bundles decrease, and $p_{\text {unc }}$ increases. $\bar{C}$ and $\bar{L}$ change together with $\bar{c}$ and $\bar{l}$, thus the cost of inequality is (approximately) unaffected by a change in uncertainty. Redistribution has the opposite effects. Taking consumption from a 'rich' agent and giving to a 'poor' agent leaves $\bar{C}$ and $\bar{L}$ constant but the right-hand side of (4) increases because of the concavity of the utility function. The cost of inequality is therefore reduced but uncertainty is not affected.

A shift in policy changes the equilibrium levels of both consumption and leisure. To measure the level effects in terms of consumption only, let us make the following definition.

Definition 7 Leisure-compensated consumption in economy $B, \hat{C}^{B}$, is defined by

$$
V\left(\left\{\hat{C}^{B}, L^{A}\right\}_{s=t}^{\infty}\right)=V\left(\left\{C^{B}, L^{B}\right\}_{s=t}^{\infty}\right)
$$

Solving for $\hat{C}^{B}$, we get

$$
\hat{C}^{B}=C^{B} \exp \left[\zeta\left(\left(1-L^{A}\right)^{1+\gamma}-\left(1-L^{B}\right)^{1+\gamma}\right)\right] .
$$

We are now ready to define the three separate welfare effects of a change from policy $A$ to policy $B$ :

Definition 8 The welfare gain of increased levels, $\omega_{\text {lev }}$, is

$$
\omega_{\text {lev }}=\frac{\hat{C}^{B}}{C^{A}}-1
$$

Definition 9 The welfare gain of reduced uncertainty, $\omega_{u n c}$, is

$$
\omega_{\text {unc }}=\frac{1-p_{u n c}^{B}}{1-p_{u n c}^{A}}-1
$$

Definition 10 The welfare gain of reduced inequality, $\omega_{\text {ine, }}$, is

$$
\omega_{\text {ine }}=\frac{1-p_{\text {ine }}^{B}}{1-p_{\text {ine }}^{A}}-1
$$


Proposition 1 establishes the relation between the utilitarian gain and the welfare decomposition. The proof is in the appendix.

Proposition 1 Assume that the utility function is separable so that for all $x, u(x c, h)=$ $f(x) u(c, h)+g(x)$. Then

$$
\omega_{U}=\left(1+\omega_{\text {lev }}\right)\left(1+\omega_{\text {unc }}\right)\left(1+\omega_{\text {ine }}\right)-1
$$

Thus, the isolated welfare gains approximately sum up to the utilitarian gain. If we are interested in the effects that a certain policy change has on risk and uncertainty in the economy, but not in distributional effects, $\omega_{l e v}+\omega_{u n c}$ is the relevant welfare measure.

As mentioned above, the certainty equivalent consumption-leisure bundles are not uniquely defined. In fact, since there is one utility level to match and two variables to determine, there is a continuum of possible choices of $\{\bar{c}, \bar{l}\}$ for each state-of-the world. I have considered two ways of determining leisure. One is to fix leisure at the level that was chosen at date $t$ in the uncertain world. The other is to set leisure to the average level in the economy. It turns out that the two approaches have different implication for the calculated $p_{\text {unc }}$ and $p_{\text {ine }}$, but that the relative changes in these costs are almost identical. ${ }^{9}$ That is, the welfare gains $\omega_{\text {unc }}$ and $\omega_{\text {ine }}$ do not seem to be sensitive to how certainty-equivalent leisure is determined. I will therefore only report results for leisure fixed at the choice level.

\section{Results}

This section examines the long-run welfare effects of debt and transfers, and what consequences different policies have on risk sharing, the distribution of resources, and economic efficiency. To illustrate how debt and transfers affect the economy and to facilitate comparisons with previous studies, each policy instrument is first studied separately. Any possible interactions between debt and transfers and the optimal mix of these two policies are considered in the second subsection. Distributional consequences of imposing the policies are explored more carefully in the third subsection. In the final subsection, I consider two variations in the tax and transfer system. First, I restrict capital incomes taxes to be zero. Next, I target transfers to households with low income and little wealth.

\footnotetext{
${ }^{9}$ When leisure is set to its average level, the cost of uncertainty is consistently higher and the cost of inequality lower. The difference between the two approaches is largest (and not always negligible) when I compare economies with lump-sum transfers to economies with means-tested transfers.
} 


\subsection{Debt and transfers in isolation}

Figures 1 and 2 depict the results of two experiments. In the first, debt is fixed at the benchmark level while transfers are lump sum and range from 0 to 30 percent of output. In the second experiment, transfers are fixed at the benchmark level and debt range from -100 percent to 250 percent of output. The figures report steady-state properties of economies with these policies, and welfare effects compared to the benchmark policy.

When debt is fixed, the optimal transfer level is 19 percent of output and the utilitarian welfare improvement over the benchmark policy is 2.6 percent of annual consumption. The separation of welfare effects shows that both inequality and uncertainty are reduced when transfers are raised. The welfare gain stemming from the reductions in inequality and uncertainty are 2.9 and 2.3 percent of annual consumption respectively. The level effect contributes negatively to welfare. The welfare loss from distortions are 2.6 percent.

These findings are unsurprising and need little discussion. That utilitarian welfare gains of increasing the transfer level can be strong was noted in Flodén and Lindé (1999). The isolated welfare effects are intuitive - a more extensive insurance program reduces inequality and uncertainty, but distorts labor supply and savings decisions. It should however be noted that if transfers are raised from a very low level, distortions may diminish (see $\omega_{\text {lev }}$ in the top-left panel in Figure 1). In a sense there is overaccumulation of capital when transfers are low. If

markets were complete, the equilibrium after-tax interest rate would be $r=1 /\left[\beta(1+g)^{1-\mu}\right]-1$, but the interest rate will always be lower when there are borrowing constraints and uncertainty (see Aiyagari, 1994). Saving is particularly costly when the interest rate is small compared to the discount rate. Therefore, a policy that crowds out physical capital can attenuate this inefficiency by shifting the interest rate closer to the discount rate.

The utilitarian welfare effects are considerably smaller when debt is varied and transfers are fixed (see Figure 2). This is in line with the results in Aiyagari and McGrattan (1998). Behind the small utilitarian effects, however, there are significant effects on inequality and uncertainty. Raising debt from its benchmark level 67 percent to the optimal 150 percent implies a utilitarian welfare gain of 0.1 percent of annual consumption. The gain from improved risk sharing is 0.8 percent and the loss from increased inequality is 0.6 percent, while the level effect is negligible.

The intuition for the distributional implications are as follows. A debt increase will raise the equilibrium interest rate and induce people to hold larger buffer stocks of savings (see Figure 5), 
hence making them better insured against income uncertainty. The improved risk sharing only benefits those with non-negligible wealth, but all households bear the costs of debt - crowding out of physical capital, higher taxes, lower wages, and lower transfers (in levels). This explains the negative impact of debt on equity.

Figure 2 also shows that debt is not particularly distortive - the level effect is even strongly positive for all except the highest debt levels. Debt has a direct crowding-out effect on physical capital while transfers only affect savings via its reduction in uncertainty and by distorting the incentives to save. Debt therefore seems more efficient than transfers for reducing the overaccumulation of capital.

The findings here are somewhat different from those in Aiyagari and McGrattan (1998) optimal debt is higher, and the welfare effects of changing the debt are larger. Two differences in the setups account for this discrepancy. First, the labor-supply elasticity is lower in the current paper, implying smaller distortions on labor supply. Second, there is considerably more idiosyncratic risk and heterogeneity in the current paper. As a consequence there is larger demand for insurance and more scope for redistribution.

\subsection{The optimal combination of debt and transfers}

The optimal combination of transfers and debt is the pair, $(\bar{B}, \bar{D}) \in \mathbf{B} \times \mathbf{D}$, which maximizes the social welfare function. The transfer and debt levels considered are $\mathbf{B}=\{0.00,0.01, \ldots, 0.30\}$, and $\mathbf{D}=\{-1.00,-0.75, \ldots, 2.50\}$. Figure 3 depicts utilitarian welfare gains of changes in policy and shows that the welfare function is maximized when transfers and debt are 0.23 and -1 , respectively. The welfare gain over the benchmark policy is then 3.4 percent of annual consumption. When agents are provided insurance from the tax system, the benefits of public debt vanish. If however redistributional effects are ignored, the optimal transfer level is around 10 percent and the optimal size of public debt is 2.5 (see top-left plot in Figure 4). ${ }^{10}$

Decomposing the welfare effects facilitates the understanding of these results. Figure 4 shows that the effects on uncertainty and inequality are the same as in the previous subsection; transfers enhance risk sharing and reduce inequality; debt enhances risk sharing but leads to more inequality. The level effects provide some new insights, however. If transfers and debt are small, there is overaccumulation of capital, and people with little wealth and low wages work

\footnotetext{
${ }^{10}$ The top-left graph in Figure 4 reports what Bénabou (1998) calls the measure of pure economic efficiency. This measure accounts for level and risk-sharing effects but ignores effects of redistribution.
} 
inefficiently hard. An increase in either transfers or debt will then relax this inefficiency, but if either transfers or debt are high an increase in the other instrument will typically be distorting. Debt also appears better suited than transfers for removing the inefficiency, because crowding out of capital directly addresses the overaccumulation of capital. Except for the lowest levels of transfers and debt, the distortions of an increase in transfers dominate these effects.

Table 1 shows some selected statistics for the U.S. economy, the benchmark economy, the economy that would be optimal according to the model, and some alternative model specifications examined below. The economy with the optimal policy does not look drastically different from the benchmark economy. Consumption is smoother while hours worked are somewhat more volatile.

The choice of wage process is critical for the amount of risk that agents face, and the degree of persistence is particularly important. The unconditional variance for the $\operatorname{AR}(1)$ process is $\sigma_{\varepsilon}^{2} /\left(1-\rho^{2}\right)$, which is sensitive to changes in persistence when $\rho$ is close to unity. There is indeed controversy over the value of $\rho$; Aiyagari and McGrattan (1998) and others use a less persistent process with $\rho=0.60$ and $\sigma_{\varepsilon}=0.24$. When I calibrate the model with this wage process (but still allow for the permanent wage differences, $\sigma_{\psi}=0.34$ ), the optimal policy combination is $B=0.16$ and $D=-1.00$, and the welfare gain over the benchmark economy is 0.7 percent of annual consumption.

One may suspect that the choice of labor-supply elasticity is important for the results since this parameter determines how labor supply is distorted by taxation. However, the results do not seem particularly sensitive to changes in the elasticity. When the elasticity is increased from 0.5 to 1 , the optimal policy becomes $B=0.20$ and $D=-0.75$. The welfare gain over the benchmark policy falls to 2.5 percent of annual consumption.

For both these variations, the decomposition of welfare effects has the same general pattern as in Figures 3 and 4. Hence the corresponding figures for the less persistent wage process and the higher elasticity are not presented here.

\subsection{Effects on inequality and distributions}

We have seen that both debt and transfers can have sizeable (positive) insurance effects. However, these two instruments work through different channels and they have opposite implications for the distribution of resources. 
Figure 5 shows how the asset distribution depends on debt and transfer levels. The most notable changes regard the fraction of agents with no wealth. When debt increases, people more willingly engage in precautionary savings (because the return on capital is higher), and it is consequently less likely that their buffer stocks are depleted. The fraction of households with no wealth is therefore small when debt is high.

The Gini coefficients reported in Figure 6 indicate that income and consumption distributions do not change significantly, but that the asset distribution becomes more compressed when debt increases. Of the Gini coefficients, the one for consumption is most closely related to agents' utility. However, there are at least two reasons why it may be a weak indicator of inequality in this setting and hence why the decomposition of welfare effects is to prefer. First, agents derive utility not only from consumption but also from leisure. Second, the consumption Gini does not distinguish variations due to inequality from fluctuations due to uncertainty.

The distributional effects of changes in transfers are more obvious. Higher benefit levels reduce uncertainty since the lowest income level improves relative to the highest income level. Higher benefits also imply lower output since increased taxes discourage work effort and saving, and since a decline in uncertainty reduces the need for precautionary saving. In addition to providing insurance, higher transfers make the tax system more redistributive. It is then not surprising that, as we see in Figures 3 and 4, the utilitarian welfare measure peaks at higher transfer levels than the measure excluding equity effects.

Figure 6 demonstrates that the model has clear predictions for how variations in transfers affect distributions of income, wealth, and consumption. As transfers increase, asset and earnings distributions become more dispersed while the distributions of consumption and gross income become more compressed. Wealth becomes more dispersed since more agents choose to hold no wealth at all when transfers are high. People with low wages do no longer have a desperate need to save in case times get even worse. With higher benefit levels, there are also less incentives for people with low wages and modest wealth to work.

Table 2 contains some additional information on the distributional effects of policy. I have conducted the following experiment. Assume that a worker observes his current productivity state $(\psi, z)$. Conditional on this information, if the worker could choose a policy $(B, D)$ and immediately move to the steady state in that economy, which policy would she choose? I have restricted the policy space to $(B, D) \in\{0.00,0.05, \ldots, 0.30\} \times\{-1.00,-0.75, \ldots, 2.50\}$. In the 
approximation of the productivity space, there is one low and one high value for permanent effects, $\psi$, and seven values for the temporary productivity, $z$. The table shows that almost all agents with low permanent productivity choose the maximum level of transfers and the minimum level of debt while the opposite holds for those with high permanent productivity.

The above exercise also hints at some interesting political-economy aspects. If the 'optimal' level of transfers is 22 percent of output, why is that level not implemented in reality? One answer could be that the political process does not implement the utilitarian welfare function. Table 2 indicates that the median voter would in fact choose a transfer level around 10 percent of output, close to the actual U.S. level. ${ }^{11}$

\subsection{Alternative tax and transfer systems}

One may argue that the results arrived at so far only apply to the specific (simplistic) tax and transfer system allowed for. For computational reasons, it has been necessary to restrict the policy space, and flat, uniform tax rates and lump-sum transfers has been a natural starting point. To examine the robustness of the previous findings, I considered some variations in the tax and transfer system. We will see that the general effects of debt and transfers do not appear to be sensitive to these changes.

\subsubsection{No capital-income taxation}

I first consider a variation in the tax system, namely setting the capital income tax rate, $\tau^{k}$, to zero. All government spending is consequently financed through taxes on labor income. One motivation for considering this specification is Judd's (1985) and Chamley's (1986) finding that the optimal steady state tax rate on capital is zero. However, Aiyagari (1995) shows that this result does not generalize to economies with incomplete markets. ${ }^{12}$

This variation has almost no impact on the results. With the benchmark policy, average utility is indistinguishable from utility in the economy with the same policy but uniform taxes. With only labor-income taxes, uncertainty is reduced somewhat but this welfare gain is offset by higher distortions on labor supply. Utilitarian welfare is now maximized when $B=.22$ and $D=-1.00$. The welfare gain over the benchmark economy is 3.15 percent of annual

\footnotetext{
${ }^{11}$ See Aiyagari and Peled (1995) for a similar exercise.

${ }^{12}$ I refer to Domeij and Heathcote (2000) for more on the optimal combination of capital and labor taxes in a similar framework.
} 
consumption.

Also the decomposition of welfare effects is similar to those in the economy with uniform taxes. Bénabou's measure of pure economic efficiency is maximized when transfers are around 10 percent and debt 250 percent. Indeed, the only clear difference from the case with uniform taxes emerges when transfers are above 25 percent. Labor supply then becomes more distorted as government expenditure must be financed by almost prohibitively high taxes on labor income. For example, when transfers are 30 percent and debt 250 percent, the tax rate is 81 percent.

\subsubsection{Means-tested transfers}

The other variation I have examined is a means-tested transfer system. This may be closer to how social insurance actually works in the U.S. Furthermore, by making the tax and transfer system more progressive, means-tested transfers may provide better insurance. However, it is also expected that saving and labor supply become more distorted for individuals with potential income close to or below the guaranteed consumption floor.

I consider two specifications of the means-tested system. With the first specification, transfers are conditioned on an agent's total resources, both income and wealth. The transfer then takes the form

$$
\widetilde{b}=\max \left[0, \underline{b}-(\bar{w} q h+(1+\bar{r}) \tilde{a}) \frac{\underline{b}}{\bar{b}}\right] .
$$

Here $\underline{b}$ is the guaranteed consumption floor and $\bar{b}$ the maximum resources allowed to qualify for welfare benefits. The ratio $\underline{b} / \bar{b}$ determines how much transfers are reduced when resources increase; when $\underline{b} / \bar{b}=1$, transfers are reduced one-for-one for every dollar of extra labor income or wealth accumulated, as in Hubbard, Skinner and Zeldes (1994, 1995). When $\bar{b}=\infty$, transfers are lump sum and $\widetilde{b}=\underline{b}$.

With the other specification, transfers are only conditioned on income,

$$
\widetilde{b}=\max \left[0, \underline{b}-(\bar{w} q h+\bar{r} \tilde{a}) \frac{b}{\bar{b}}\right] .
$$

Table 3 shows results for different values of $\underline{b} / \bar{b}$ with the benchmark policy in these transfer systems. $^{13}$ The variations in results are striking. In particular, welfare is low when means testing is strict (i.e. when $\underline{b} / \bar{b}=1$ ). I have looked closer at two of these transfer sytems - the

\footnotetext{
${ }^{13}$ The consumption floor then varies between 13.3 and 25.6 percent of output. According to Hubbard, Skinner, and Zeldes (1994), the consumption floor was approximately $\$ 7,200$ in 1984 for a representative family receiving AFDC and food stamps. If this family (female-headed with two children) is approximated as two consumptionequivalent units, the consumption floor per consumption unit was 18 percent of output.
} 
one conditioning strictly on income and wealth and the one that yields the highest welfare in Table $1 .{ }^{14}$

With strict means testing, agents with low wages and little wealth choose to live on transfers and not to work. As a consequence, average labor supply is considerably lower than in the economy with lump-sum transfers. Since those who stop working have low productivity, labor supply in efficiency units is not reduced to the same extent. By shifting the labor burden towards the highly productive workers, agents in this economy thus enjoy more leisure without experiencing a large reduction in efficient labor supply. The welfare decomposition consequently shows that there is a positive level effect compared to the economy with lump-sum transfers.

Nevertheless, average utility is considerably lower when transfers are strictly means tested rather than lump sum. The welfare loss is due to substantial increases in uncertainty and inequality. The decomposition of these welfare effects is sensitive to how certainty-equivalent leisure is specified. ${ }^{15}$ The general effects of debt seem robust, however. Higher debt implies more risk sharing and more inequality, and average utility increases in debt if transfers are low.

At first sight, it may be surprising that risk sharing deteriorates and inequality increases with this transfer system, since means-tested transfers are targeted at low-income households. Hubbard, Skinner and Zeldes (1995) provide the intuition: With strictly means-tested insurance programs, incentives to save and work are extremely weak for households with potential income close to or below the consumption floor. Since these households do not save, their chances of moving away from the bottom end of the distribution are small. The effects on the wealth distribution are clear. In the benchmark economy the wealthiest 20 percent of agents hold 61 percent of the assets. With strictly means-tested transfers this fraction increases to 78 percent. The Gini coefficients for wealth and consumption, reported in Table 3, also increase.

The transfer system that only conditions on income does not discourage asset accumulation to the same extent as the first transfer system. When the testing is soft $(\underline{b} / \bar{b}=.1)$ welfare turns out to be higher than with lump sum transfers. Figure 7 depicts welfare effects of different levels

\footnotetext{
${ }^{14}$ Only a limited set of policy combinations is considered because of computation costs. Furthermore, to reduce problems with discrete jumps in aggregate labor supply in response to changes in the transfer level, I use a Markov chain with $2 \times 11$ productivity levels (instead of $2 \times 7$ ). The results are compared to a benchmark economy with lump-sum transfers but with the same $2 \times 11$ Markov chain.

${ }^{15}$ In short, the explanation for this sensitivity is that labor supply becomes volatile when transfers are meanstested, and in particular that many agents choose not to work at all. It then matters if certainty-equivalent leisure is fixed at the choice level or at its average level. With leisure fixed at the initial choice level, most of the welfare losses are accredited to inequality effects, while most welfare losses are accredited to increased uncertainty when leisure is fixed at the average.
} 
of debt and transfers in this transfer system. The general pattern of the effects is similar to that with lump-sum transfers. The same holds for the decomposition of the welfare effects (not reported in the figure). Average utility is maximized when transfers are 16 percent of output and debt is -100 percent. The welfare gain is then 2.8 percent compared to the economy with lump-sum transfers and benchmark policy.

These experiments have shown that the outcome and effectiveness of means-tested transfer systems are sensitive to how the system is designed. If the system discourages asset accumulation of low-income households, welfare may become considerably lower than when transfers are lump sum. A well designed program, however, appears able to provide effective insurance even when the transfer program is only of modest size. Still, none of the means-tested programs that I have examined achieved as high welfare as the optimal system with lump-sum transfers.

\section{Summary and conclusion}

This study has shown that even if changes in government debt have little impact on a utilitarian welfare measure, the insurance value of increasing debt can be large. Further, utilitarian welfare effects of debt only appear to be negligible when transfers are around today's level. The positive insurance effects are then just offset by negative effects on equity. Welfare gains of increasing transfer levels can be large, both because of additions to insurance and to equity.

In providing insurance and redistribution, transfers will work more efficiently than public debt when a utilitarian welfare criterion is used. In fact, when the government is allowed to choose transfers optimally, the role for public debt disappears and the optimal level of debt is -100 percent of output. If, however, redistributive effects are ignored when policy is evaluated, a totally different picture emerges. The optimal policy is then to have as high debt as possible (250 percent of output) and to let transfers be at the current level.

According to the model, the welfare gains of shifting from today's level of debt (67 percent of output) and transfers (8.2 percent) to the optimal levels, -100 and 23 percent respectively, would be 3.4 percent of annual consumption. This analysis abstracts from the welfare benefits or losses associated with the transition to the new steady state. The capital stock will decrease in the transition from a steady state with low transfers to one with high transfers. There are then extra welfare gains from the transition, since part of the capital stock can be consumed in the transition. On the other hand, reducing debt is costly during the transition. In that 
transition, debt must be repaid and additional investments in physical capital are needed.

If reducing the public debt from today's level is not politically feasible, the optimal transfer level is 19 percent of output and the welfare gain over current policy is 2.6 percent of annual consumption. 


\section{References}

Aiyagari, S. Rao, 1994, Uninsured Idiosyncratic Risk and Aggregate Saving, Quarterly Journal of Economics, 109, 311-331.

Aiyagari, S. Rao, 1995, Optimal Capital Income Taxation with Incomplete Markets, Borrowing Constraints, and Constant Discounting, Journal of Political Economy, 103, 1158-1175.

Aiyagari, S. Rao, and Ellen R. McGrattan, 1998, The Optimum Quantity of Debt, Journal of Monetary Economics, 42, 447-469.

Aiyagari, S. Rao, and Dan Peled, 1995, Social Insurance and Taxation Under Sequential Majority Voting and Utilitarian Regimes, Federal Reserve Bank of Minneapolis, Research Department Staff Report 197.

Altonji, Joseph G., 1986, Intertemporal Substitution in Labor Supply: Evidence from Micro Data, Journal of Political Economy, 94, S176-S215.

Atkeson, Andrew, and Robert E. Lucas, Jr., 1995, Efficiency and Equality in a Simple Model of Efficient Unemployment Insurance, Journal of Economic Theory, 66, 64-88.

Attanasio, Orazio, and Stephen J. Davis, 1996, Relative Wage Movements and the Distribution of Consumption, Journal of Political Economy, 104, 1227-1262.

Ball, Laurence, and N. Gregory Mankiw, 1995, What Do Budget Deficits Do? in: Budget Deficits and Debt: Issues and Options, Symposium Proceedings, Federal Reserve Bank of Kansas City.

Barro, Robert J., 1979, On the Determination of the Public Debt, Journal of Political Economy, 87, 940-971.

Bénabou, Roland, 1998, Macroeconomics and Public Finance with Heterogenous Agents: What Level of Redistribution Maximize Income and Efficiency?, manuscript, New York University.

Card, David, 1991, Intertemporal Labor Supply: An Assessment, NBER Working Paper, No. 3602. 
Chamley, Christophe, 1986, Optimal Taxation of Capital Income in General Equilibrium with Infinite Lives, Econometrica, 54, 607-622.

Chari, V.V., Lawrence J. Christiano, and Patrick J. Kehoe, 1994, Optimal Fiscal Policy in a Business Cycle Model, Journal of Political Economy, 102, 617-652.

Cole, Harold L., and Narayana Kocherlakota, 1998, Efficient Allocations With Hidden Income and Hidden Storage, Federal Reserve Bank of Minneapolis, Research Department Staff Report 238.

Díaz-Giménez, Javier, Vincenzo Quadrini, José-Víctor Ríos-Rull, 1997, Dimensions of Inequality: Facts on the U.S. Distributions of Earnings, Income, and Wealth, Federal Reserve Bank of Minneapolis Quarterly Review, 21, 3-21.

Domeij, David, and Jonathan Heathcote, 2000, Capital versus Labor Income Taxation with Heterogenous Agents, manuscript, Stockholm School of Economics.

Flodén, Martin, and Jesper Lindé, 1999, Idiosyncratic Risk in the U.S. and Sweden: Is there a Role for Government Insurance?, manuscript, Stockholm School of Economics.

Gale, Douglas, 1990, The Efficient Design of Public Debt, in: Rudiger Dornbusch and Mario Draghi, eds.: Public Debt Management: Theory and History, Cambridge University Press.

Ghez, Gilbert R. and Gary S. Becker, 1975, The Allocation of Time and Goods over the Life Cycle, Columbia University Press.

Hubbard, R. Glenn, Jonathan Skinner, and Stephen P. Zeldes, 1994, The importance of Precautionary Motives in Explaining Individual and Aggregate Savings, Carnegie-Rochester Conference Series on Public Policy, 40, 59-125.

Hubbard, R. Glenn, Jonathan Skinner, and Stephen P. Zeldes, 1995, Precautionary Saving and Social Insurance, Journal of Political Economy, 103, 360-399.

Huggett, Mark, 1993, The Risk Free Rate in Heterogeneous-Agents, Incomplete Insurance Economies, Journal of Economic Dynamics and Control, 17, 953-970.

Jappelli, Tullio, 1990, Who is Credit Constrained in the U.S. Economy?, Quarterly Journal of Economics, 105, 219-34. 
Judd, Kenneth L., 1985, Redistributive Taxation in a Simple Perfect Foresight Model, Journal of Public Economics, 28, 59-83.

King, Robert G., Charles I. Plosser, and Sergio Rebelo, 1988, Production, Growth and Business Cycles: I. The Basic Neoclassical Model, Journal of Monetary Economics, 21, 195-232.

Krueger, Dirk, and Fabrizio Perri, 1998, Risk Sharing: Private Insurance Markets or Redistributive Taxes?, manuscript, Federal Reserve Bank of Minneapolis Research Department.

Lucas, Robert E. Jr., and Nancy L. Stokey, 1983, Optimal Fiscal and Monetary Policy in an Economy Without Capital, Journal of Monetary Economics, 12, 55-93.

MaCurdy, Thomas E., 1981, An Empirical Model of Labor Supply in a Life-Cycle Setting, Journal of Political Economy, 89, 1059-1085.

Storesletten, Kjetil, Chris I. Telmer, and Amir Yaron, 1997, Consumption and Risk Sharing over the Life Cycle, manuscript, Carnegie Mellon University.

Tauchen, George, 1986, Finite State Markov Chain Approximations to Univariate and Vector Autoregressions, Economics Letters, 20, 177-181.

Varian, Hal R., 1980, Redistributive Taxation as Social Insurance, Journal of Public Economics, 14, 49-68.

Woodford, Michael, 1990, Public Debt as Private Liquidity, American Economic Review Papers and Proceedings, 80, 382-388.

Zeldes, Stephen, 1989, Consumption and Liquidity Constraints: An Empirical Investigation, Journal of Political Economy, 97, 305-346. 


\section{Appendix: $\quad$ Proof of Proposition 1}

From Definitions 1 and 6, we obtain

$$
u\left(\left(1-p_{\text {ine }}\right) \bar{C}, 1-\bar{L}\right)=\int u(\bar{c}, 1-\bar{l}) d \lambda
$$

Definitions 1 and 5 imply that $u\left(\left(1-p_{\text {unc }}\right) C, 1-L\right)=u(\bar{C}, 1-\bar{L})$. By construction, $\bar{L}=L$, hence $\left(1-p_{\text {unc }}\right) C=\bar{C}$ which is used in (A.1) to get

$$
u\left(\left(1-p_{\text {unc }}\right)\left(1-p_{\text {ine }}\right) C, 1-L\right)=\int u(\bar{c}, 1-\bar{l}) d \lambda .
$$

Next, note that by Definition 2

$$
\sum_{s=t}^{\infty} \beta^{s-t} u(\bar{c}, 1-\bar{l})=\mathrm{E}_{t} \sum_{s=t}^{\infty} \beta^{s-t} u(c, 1-l) .
$$

Together with (A.2) this results in

$$
\sum_{s=t}^{\infty} \beta^{s-t} u\left(\left(1-p_{\text {unc }}\right)\left(1-p_{\text {ine }}\right) C, 1-L\right)=\int \mathrm{E}_{t} \sum_{s=t}^{\infty} \beta^{s-t} u(c, 1-l) d \lambda .
$$

The definition of utilitarian welfare gain therefore implies that

$$
\begin{aligned}
& \sum_{s=t}^{\infty} \beta^{s-t} u\left(\left(1+\omega_{U}\right)\left(1-p_{\text {unc }}^{A}\right)\left(1-p_{\text {ine }}^{A}\right) C^{A}, 1-L^{A}\right) \\
= & \sum_{s=t}^{\infty} \beta^{s-t} u\left(\left(1-p_{\text {unc }}^{B}\right)\left(1-p_{\text {ine }}^{B}\right) C^{B}, 1-L^{B}\right) .
\end{aligned}
$$

Now note that by definition $u\left(\hat{C}^{B}, 1-L^{A}\right)=u\left(C^{B}, 1-L^{B}\right)$, and by assumption $u(x c, 1-l)=$ $f(x) u(c, 1-l)+g(x)$. Consequently,

$$
u\left(\left(1-p_{\text {unc }}^{B}\right)\left(1-p_{\text {ine }}^{B}\right) C^{B}, 1-L^{B}\right)=u\left(\left(1-p_{\text {unc }}^{B}\right)\left(1-p_{\text {ine }}^{B}\right) \hat{C}^{B}, 1-L^{A}\right) .
$$

By using (A.4) in (A.3) we get

$$
\left(1+\omega_{U}\right)\left(1-p_{\text {unc }}^{A}\right)\left(1-p_{\text {ine }}^{A}\right) C^{A}=\left(1-p_{\text {unc }}^{B}\right)\left(1-p_{\text {ine }}^{B}\right) \hat{C}^{B} .
$$

After rearranging and using Definitions 8-10 we obtain

$$
\omega_{U}=\left(1+\omega_{\text {lev }}\right)\left(1+\omega_{\text {unc }}\right)\left(1+\omega_{\text {ine }}\right)-1 .
$$




\begin{tabular}{lrrrrrrrrrr} 
& \multicolumn{10}{c}{ Model economies } \\
\cline { 3 - 12 } Statistic & U.S. & \multicolumn{1}{c}{$(1)$} & \multicolumn{1}{c}{$(2)$} & \multicolumn{1}{c}{$(3)$} & \multicolumn{1}{c}{$(4)$} & \multicolumn{1}{c}{$(5)$} & $(6)$ & $(7)$ & $(8)$ & $(9)$ \\
\hline interest rate, pre-tax & $4.50^{a}$ & 4.50 & 5.46 & 4.50 & 4.50 & 3.05 & 3.11 & 5.08 & 5.45 & 5.25 \\
interest rate, post-tax & $\mathrm{n} / \mathrm{a}$ & 2.82 & 2.55 & 2.81 & 2.81 & 3.05 & 3.11 & 3.17 & 3.41 & 2.91 \\
capital-output ratio & $2.50^{a}$ & 2.50 & 2.32 & 2.50 & 2.50 & 2.84 & 2.83 & 2.39 & 2.32 & 2.35 \\
hours & $.33^{b}$ & .29 & .26 & .30 & .30 & .29 & .25 & .21 & .28 & .27 \\
efficiency hours & $\mathrm{n} / \mathrm{a}$ & .32 & .28 & .34 & .31 & .31 & .28 & .28 & .30 & .29 \\
tax rate & $.38^{a}$ & .38 & .53 & .38 & .38 & .44 & .61 & .37 & .37 & .45 \\
c.v., hours & $\mathrm{n} / \mathrm{a}$ & .16 & .18 & .27 & .13 & .17 & .19 & .71 & .16 & .16 \\
c.v., consumption & $\mathrm{n} / \mathrm{a}$ & .46 & .37 & .27 & .31 & .45 & .35 & .50 & .42 & .38 \\
c.v., disp. income & $\mathrm{n} / \mathrm{a}$ & .77 & .71 & .86 & .50 & .77 & .71 & .87 & .72 & .67 \\
gini, consumption & $\mathrm{n} / \mathrm{a}$ & .25 & .21 & .27 & .17 & .25 & .19 & .28 & .23 & .21 \\
gini, wealth & $.78^{c}$ & .61 & .72 & .62 & .43 & .59 & .68 & .76 & .64 & .70 \\
gini, disp. income & $.57^{c}$ & .37 & .33 & .40 & .27 & .37 & .34 & .43 & .35 & .32 \\
gini, earnings & $.63^{c}$ & .42 & .43 & .46 & .31 & .42 & .44 & .54 & .41 & .41
\end{tabular}

Description of model economies:

(1) benchmark specification and benchmark policy

(2) benchmark specification, optimal policy $(B=.23$ and $D=-1.00)$

(3) high labor-supply elasticity $(\gamma=1)$, benchmark policy

(4) less income risk ( $\rho=.60$ and $\left.\sigma_{\varepsilon}=.24\right)$, benchmark policy

(5) no capital-income taxation, benchmark policy

(6) no capital-income taxation, optimal policy $(B=.22$ and $D=-1.00)$

(7) transfers conditioned on income and wealth, strict version $(\underline{b} / \bar{b}=1)$, benchmark policy

(8) transfers conditioned on income, $\underline{b} / \bar{b}=.1$, benchmark policy

(9) transfers conditioned on income, $\underline{b} / \bar{b}=.1$, optimal policy $(B=.16$ and $D=-1.00)$

Note: Values in italics have been calibrated to match U.S. data. Coefficients of variation are calculated on the cross-section of individuals.

Sources: ${ }^{a)}$ Aiyagari and McGrattan (1998). ${ }^{b)}$ Ghez and Becker (1975). ${ }^{c)} 1992$ Survey of Consumer Finances as reported in Díaz-Giménez et.al. (1997). 
Table 2. Optimal Policy Conditional on Idiosyncratic State

\begin{tabular}{lccccccc}
\hline \hline & \multicolumn{3}{c}{ Low $\psi$} & & \multicolumn{3}{c}{ High $\psi$} \\
\cline { 2 - 4 } \cline { 6 - 8 }$z$ & $w$ & $B^{*}$ & $D^{*}$ & & & $B^{*}$ & $D^{*}$ \\
\hline$z_{1}$ & .14 & .30 & -1.00 & & .27 & .15 & 2.50 \\
$z_{2}$ & .22 & .30 & -1.00 & & .43 & .10 & 2.50 \\
$z_{3}$ & .35 & .30 & -1.00 & & .70 & .05 & 2.50 \\
$z_{4}$ & .57 & .30 & -1.00 & & 1.13 & .00 & 2.50 \\
$z_{5}$ & .93 & .30 & -1.00 & & 1.83 & .00 & 2.50 \\
$z_{6}$ & 1.50 & .25 & -1.00 & & 2.97 & .00 & 2.50 \\
$z_{7}$ & 2.44 & .05 & 2.50 & 4.81 & .00 & 2.50 \\
\hline \hline
\end{tabular}

Note: $w$ is the present wage, given by the productivity state $(\psi, z)$, and $\left(B^{*}, D^{*}\right)$ is the policy (transfers, debt) that the agent would choose if he could make a once-and-forever decision on policy and if the economy would immediately transfer to the new steady state. 
Table 3. Different transfer systems

\begin{tabular}{|c|c|c|c|c|c|c|c|c|}
\hline \multicolumn{2}{|l|}{ Transfer system } & \multirow[b]{2}{*}{$\underline{b}$} & \multirow[b]{2}{*}{$\omega^{U}$} & \multirow[b]{2}{*}{$H$} & \multicolumn{2}{|c|}{ Gini } & \multicolumn{2}{|c|}{$\%$ of wealth held by } \\
\hline Test criterion & $\underline{b} / \bar{b}$ & & & & wealth & cons. & top $20 \%$ & top $5 \%$ \\
\hline none (lump sum) & 0 & 8.2 & 0.0 & .31 & .60 & .24 & 61 & 25 \\
\hline income + wealth & 1 & 25.6 & -9.2 & .28 & .76 & .28 & 78 & 34 \\
\hline income + wealth & .5 & 25.1 & -0.7 & .29 & .82 & .26 & 90 & 42 \\
\hline income + wealth & .1 & 14.6 & -3.0 & .30 & .86 & .26 & 96 & 48 \\
\hline income & 1 & 24.1 & -9.8 & .28 & .71 & .28 & 73 & 32 \\
\hline income & .5 & 24.2 & -1.4 & .29 & .77 & .25 & 81 & 39 \\
\hline income & .1 & 13.3 & 1.2 & .30 & .64 & .23 & 65 & 28 \\
\hline
\end{tabular}

Note: $\underline{b}$ is expressed in percent of output, $\omega^{U}$ is the utilitarian welfare gain compared to the benchmark economy (with the extended productivity grid, see footnote 14), and $H$ is the aggregate labor supply in efficiency units. 
Figure 1. Effects of Transfers
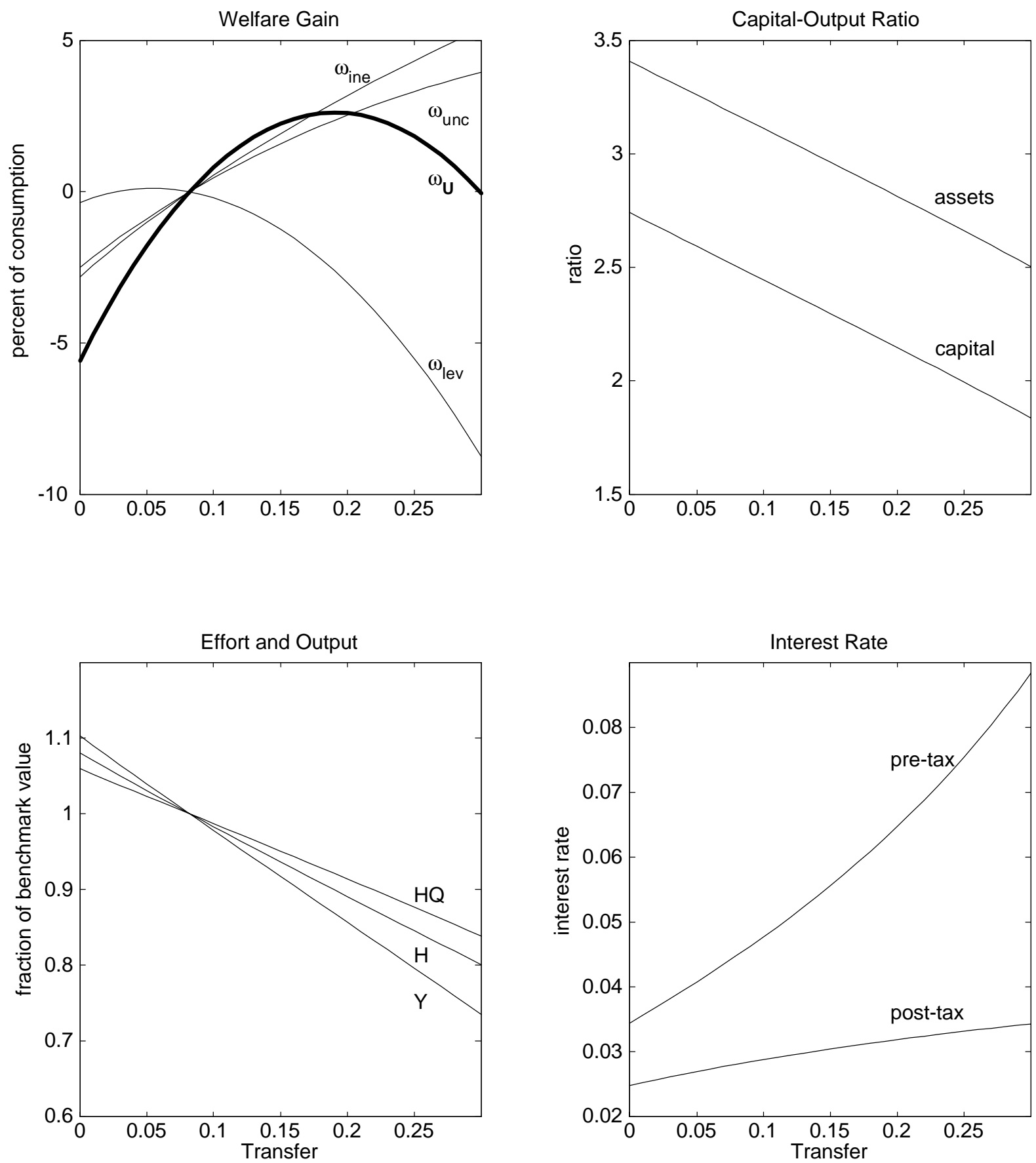

Note: $H$ is aggregate labor supply, $H Q$ is aggregate labor supply in efficiency units, $Y$ is aggregate production. 'Assets' are capital plus debt. Assets, capital and transfer are expressed as fractions of output. 
Figure 2. Effects of Government Debt
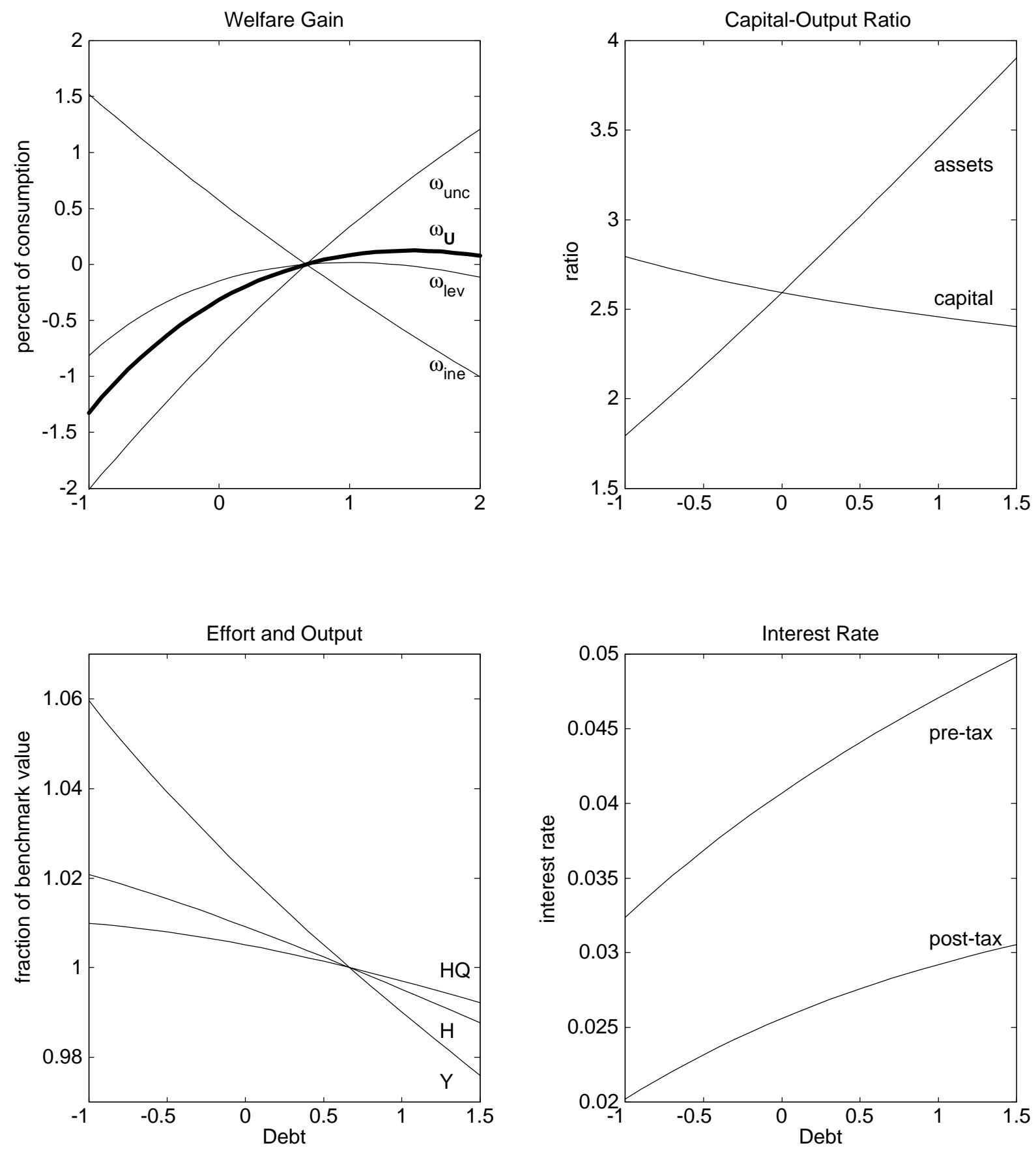

Note: Debt is expressed as a fraction of output. See also Figure 1. 


\section{Figure 3. Utilitarian Welfare Gain of Policy Change}

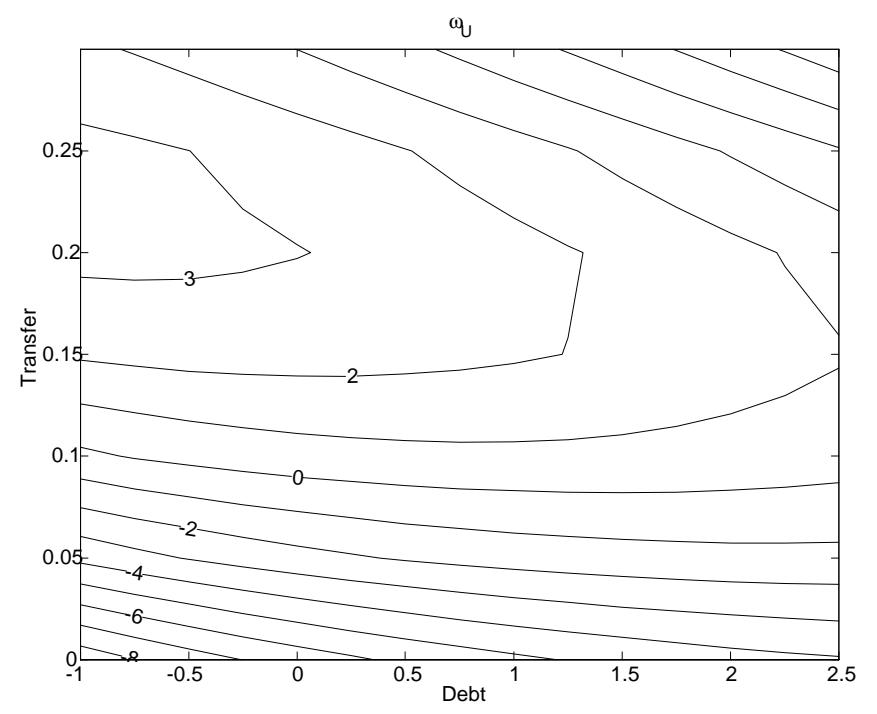

Note: The contour lines represent welfare gains, in percent of annual consumption, of changing from the benchmark policy to a policy with the indicated transfer and debt. 
Figure 4. Decomposition of Welfare Gain
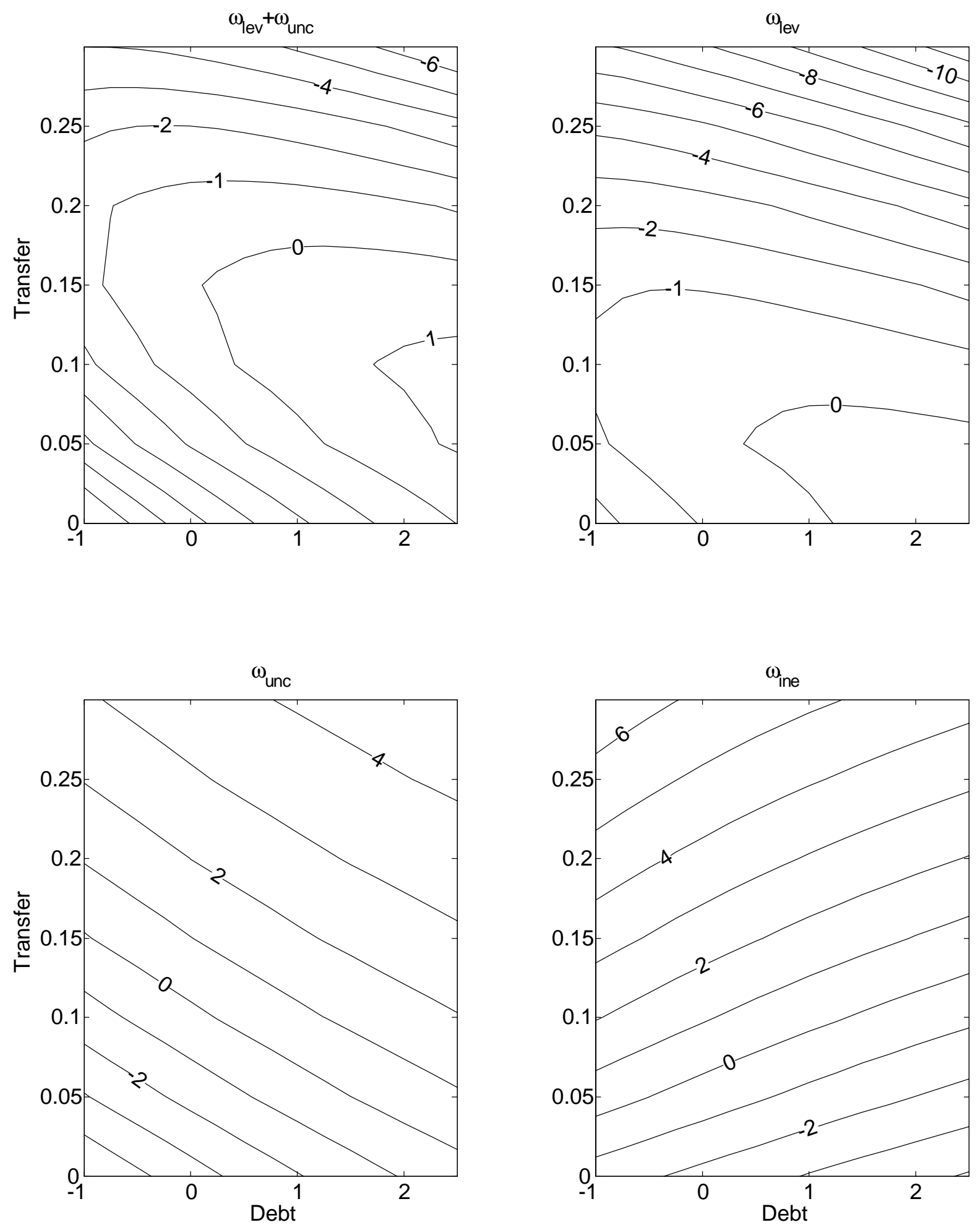

Note: See Figure 3. 
Figure 5. Wealth Distributions

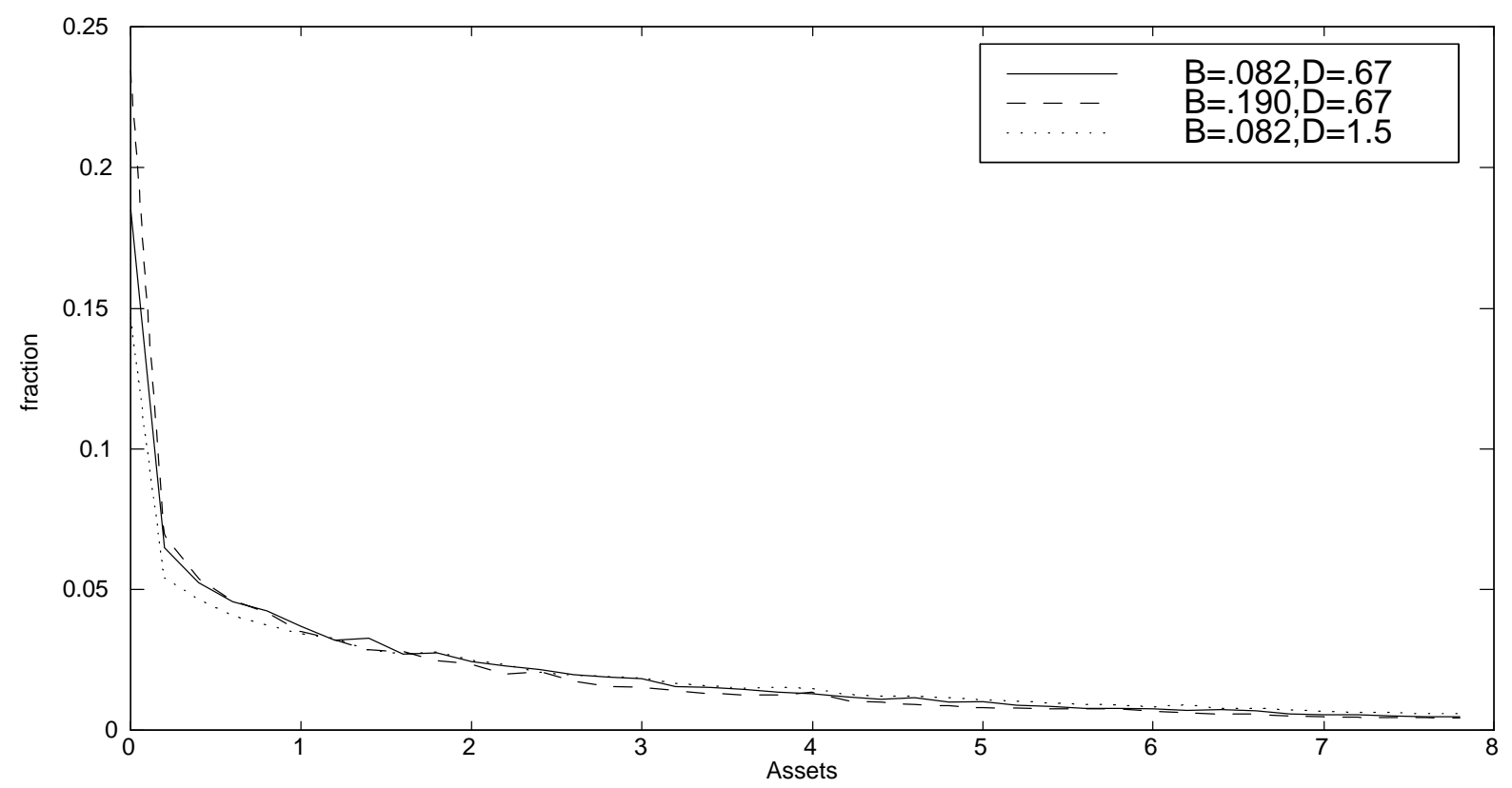

Note: The graph shows the fraction of agents with asset holdings belonging to bins of size 0.2 For example, in the benchmark economy approximately 18 percent of agents hold assets worth less than .2. Asset holdings are expressed as fractions of output. 
Figure 6. Distribution Effects of Debt and Transfers
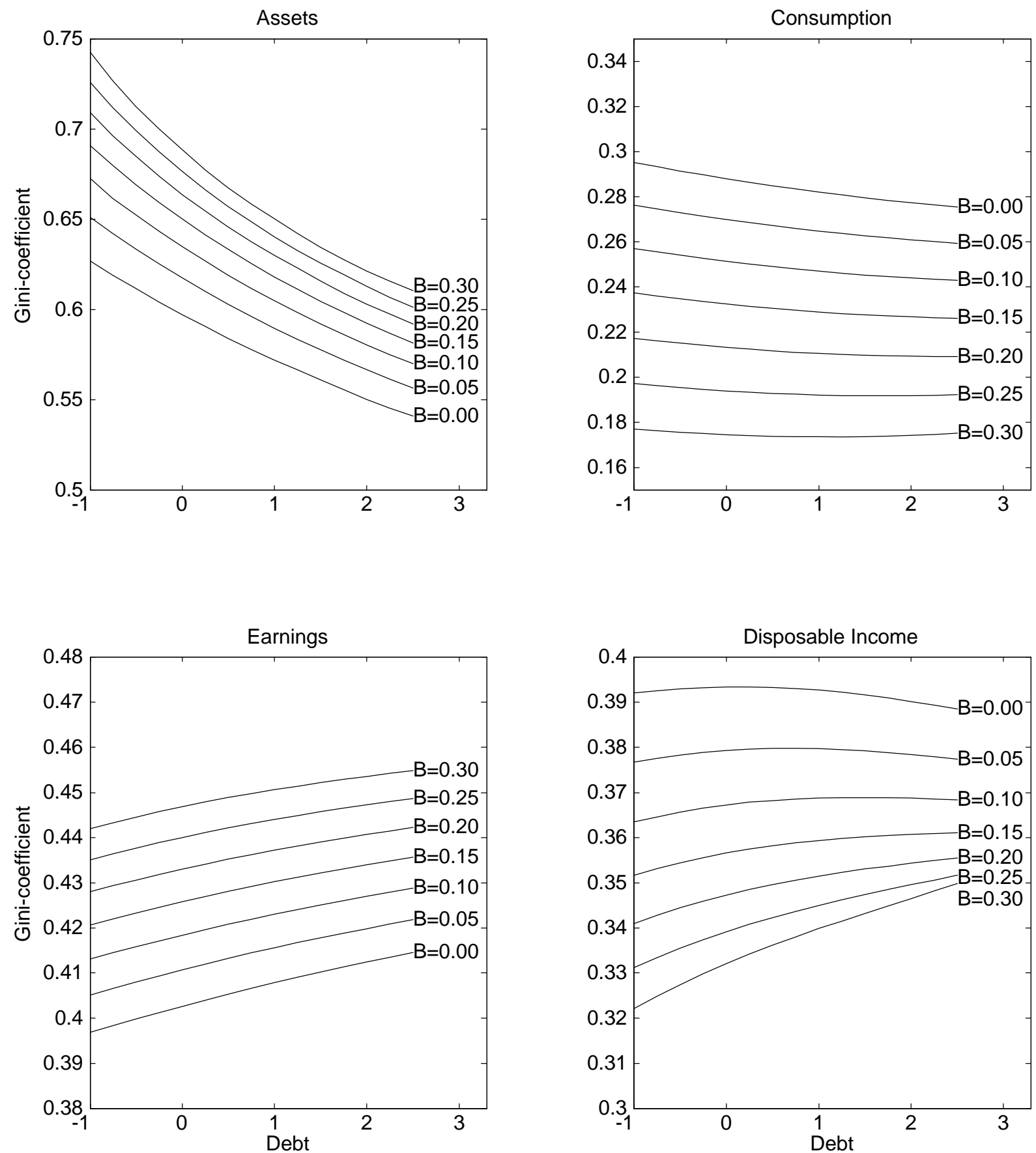

Note: Disposable income is total pre-tax income including transfers. $D$ is the debt level as a fraction of output and $B$ is the transfer level. 
Figure 7. Income-Tested Transfers, $\underline{b} / \bar{b}=0.1$
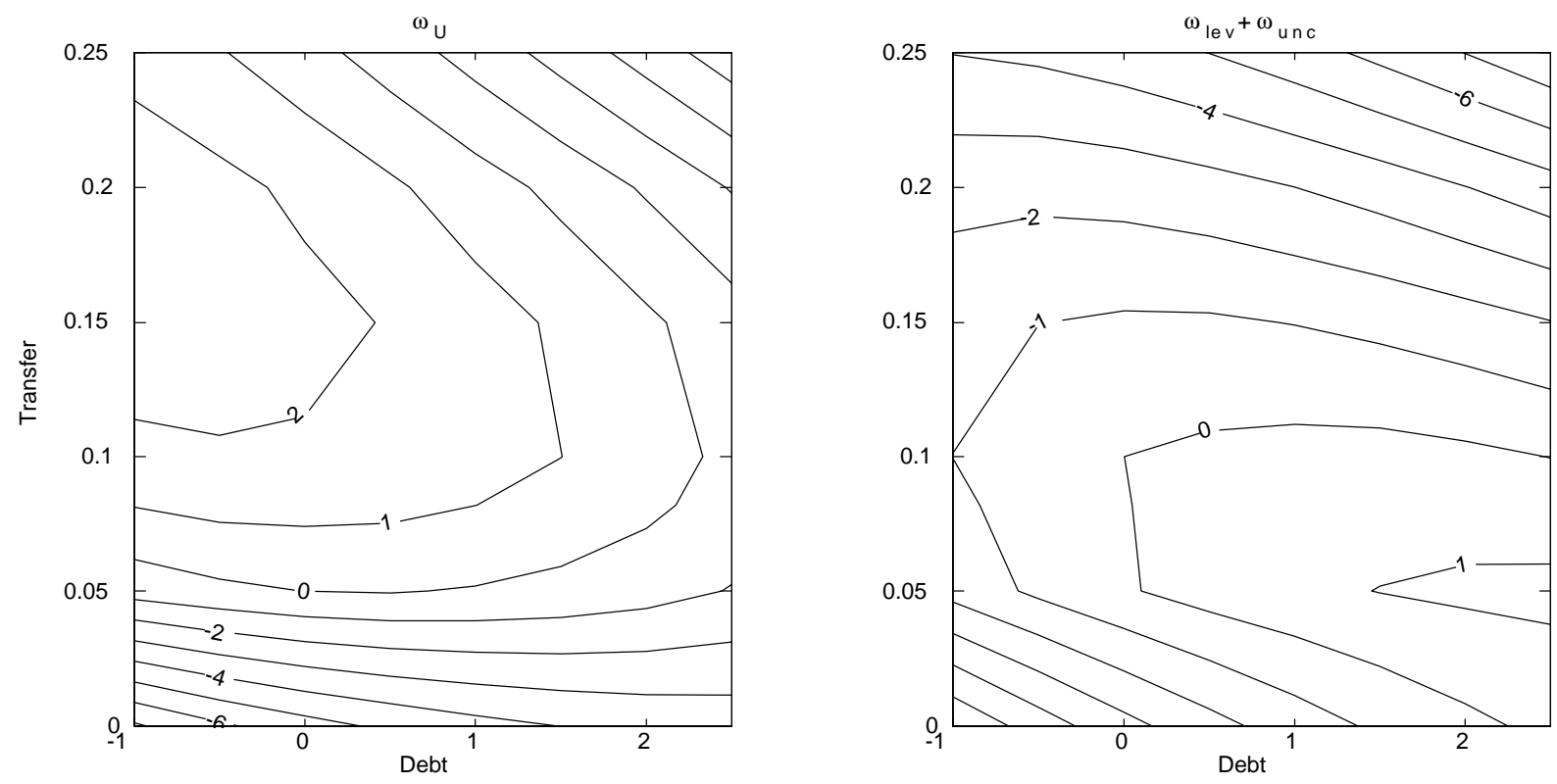

Note: Welfare gains are relative to the economy with lump-sum transfers and benchmark policy. See also Figure 3. 